Удк 616.311.2-002+616-092.9: 616-076.1

DOI 10.11603/2311-9624.2021.3.12462

\author{
(СР. О. Древніцька, О. В. Авдєєв, А. Б. Бойків
}

Тернопільський національний медичний університет імені І. Я. Горбачевського МОЗ України E-mail: avdeev@tdmu.edu.ua

\title{
Структурні зміни тканин пародонта при експериментальному гінгівіті з гіперергічним перебігом запального процесу
}

\section{ІНФОРМАЦІЯ}

Надійшла до редакціï/Received: 03.08.2021 p.

Ключові слова: гінгівіт; перебіг запальної реакції; структурні зміни ясен.

\section{АНОТАЦІЯ}

Резюме. Для оцінки морфологічних змін у тканинах пародонта при експериментальному гінгівіті з гіперергічним перебігом запального процесу було проведено моделювання цієї патології та експериментального гінгівіту без впливу на перебіг запальної реакції. Контролем слугували гістопрепарати тканин пародонта інтактних щурів.

Мета дослідження - вивчити морфологічні зміни тканин пародонта при експериментальному гінгівіті з гіперергічним перебігом запального процесу.

Матеріали і методи. Проведено морфологічні дослідження альвеолярного відростка із зубами та тканинами пародонта інтактних щурів і щурів із експериментальним гінгівітом віком 5-6 місяців. Мікроскопічно досліджували та фотодокументували зрізи товщиною 6-7 мкм, які були зафарбовані гематоксиліном та еозином.

Результати досліджень та їх обговорення. У щурів нормоергічної групи в епітеліальному пласті спостерігали розширення міжклітинних просторів, інфільтрацію нейтрофілами. Субепітеліальні тканини також були інфільтровані лейкоцитарними елементами. Найбільших змін зазнавали міжзубні ясенні сосочки, які були щільно інфільтровані нейтрофілами, місцями некротизовані. У щурів з експериментальним гінгівітом і гіперергічним перебігом запальної реакції спостерігали зміни епітелію, що відповідають неспецифічному запальному процесу. Практично усі міжзубні сосочки укриті виразками або частково некротизовані, епітелій підростає під некротичні маси, місцями наявна гіперплазія епітелію, особливо верхівок міжзубних ясенних сосочків. Окрім лейкоцитів, в епітелії ясен визначають мікрокісти з елементами ороговіння.

Висновки. Результати проведених гістологічних досліджень показали зміни структури ясен тварин при експериментальному гінгівіті без зміни реактивності організму. Зокрема, спостерігали деструктивні зміни епітеліального та сполучнотканинного шарів слизової оболонки; були наявні зміни епітелію: потовщення його зроговілого шару, ущільнення зернистого та остистого шарів; сполучної тканини: явища набряку, лейкоцитарної інфільтрації. При моделюванні гіперергічного гінгівіту в пародонті виникав запальний процес, який характеризувався розвитком значної лейкоцитарної інфільтрації епітеліального пласту; часто спостерігали як некротизацію ясенного сосочка, так і його гіперплазію з проліферацію епітелію. 
Вступ. Ураховуючи етіологічні фактори захворювань тканин пародонта, зокрема стан гігієни ротової порожнини, наявність мікроорганізмів і продуктів їх життєдіяльності та стан реактивності організму, який формує відповідь на патогенну дію, найменш дослідженим є питання визначення перебігу запальної реакції в яснах і прогнозування перебігу захворювання. Результати проведених морфологічних досліджень показують відмінності різних ділянок ясен та їх функціональної активності у людей [1]; є повідомлення про зміни імунологічних показників [2] при експериментальному пародонтиті. Тому актуальним було дослідження структурних зміни тканин пародонта при моделюванні експериментального гінгівіту з гіперергічним перебігом запальної реакції.

Метою дослідження було вивчити морфологічні зміни тканин пародонта при експериментальному гінгівіті з гіперергічним перебігом запального процесу.

Матеріали і методи. Експеримент був проведений на щурах-самцях віком 5-6 місяців. Експериментальний гінгівіт із гіперергічним перебігом запальноїреакціївикликализа допомогою імунотропного препарату «Пірогенал» та місцевого впливу ультразвуку частотою 50 кГц, потужністю випромінювання від 1,0 до 1,2 Вт/см ${ }^{2}$ при експозиції коливань 45 с, торкаючись в приясенній ділянці нижнього різця [3]. Експериментальний гінгівіт із нормергічним перебігом запальної реакції викликали, використовуючи тільки вплив ультразвуку за вищевказаною методикою. Гістологічному дослідженню піддавали альвеолярний відросток із зубами і тканинами пародонта 10 інтактних щурів та 20 щурів з експериментальним гінгівітом із різним перебігом запальної реакції. Блоки нижньої щелепи із зубами і яснами фіксували в $10 \%$ розчині нейтрального формаліну, декальцинували в 5 \% розчині азотної кислоти. Контроль часу витримки зразків у декальцинуючій рідині проводили шляхом проколювання кістки препарувальною голкою. Після проводки за спиртами висхідної концентрації тканини заливали в целоїдин-парафін. 3 блоків виготовляли зрізи товщиною 6-7 мкм, які зафарбовували гематоксиліном та еозином [4].

Світлооптичне дослідження препаратів проводили під мікроскопом та документували. Препарати ясен фотографували за допомогою мікроскопа MICROmed SEO SCAN і відеокамери Vision CCD Camer із наступним аналізом.
Морфологічні дослідження проведено разом із працівниками морфологічного сектора Міжкафедральної навчально-дослідної лабораторії (завідувач сектора - проф. 3. М. Небесна). Усі дослідження були проведені з дотриманням біоетичних вимог щодо хребетних тварин, яких використовують для дослідних та інших наукових цілей (Страсбург, 1986) (протокол засідання комісії з біоетики № 62 від 11 січня 2021 року).

Результати досліджень та їх обговорення. Аналіз морфології слизової оболонки альвеолярних ясен показав, що зроговілий шар має ділянки стоншення, в деяких місцях він відшарувався. У клітинах зернистого шару наявні базофільні гранули. Нижче розташовані клітини полігональної форми - шар шипоподібних клітин - 7-8 рядів та базальний шар, в якому деякі клітини містяться у мітозі. Таке розташування шарів епітелію свідчить про ортокератоз. У сполучній тканині слизової оболонки ясен, яка складається з пучків оксифільних колагенових волокон, базофільно зафарбованих сполучнотканинних клітин, наявні світлі ділянки аморфного компоненту (рис. 1).

Наявна невелика інфільтрація власної пластинки лімфоцитами. Цемент кореня зуба представлений клітинним і безклітинним компонентами, які були чітко розділені; поверхня зуба була гладенькою. Багатошаровий плоский зроговілий епітелій рівномірно вкри-

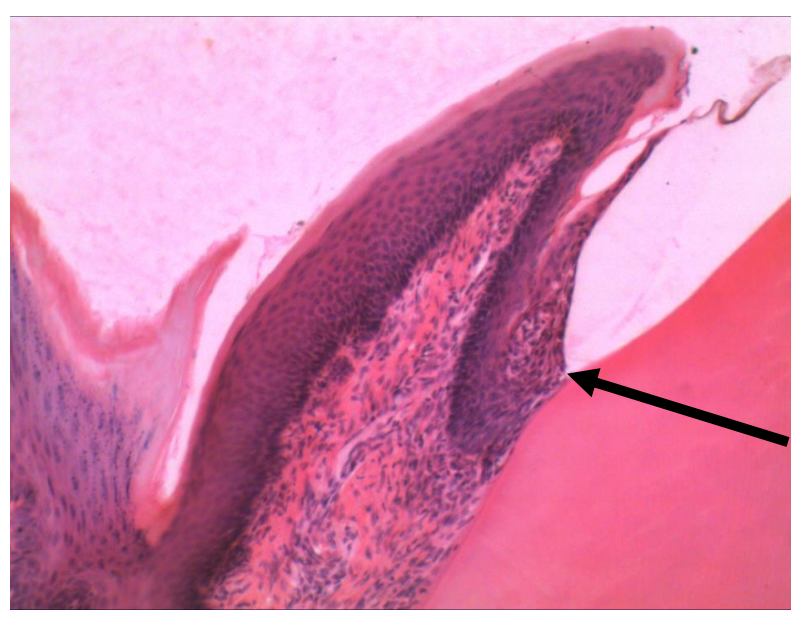

Puc. 1. Слизова оболонка ясен та порожнини рота інтактного щура, вкрита компактним шаром зроговілого епітелію. Межа між зроговілими та життєздатними клітинами чітка. Ясенний сосочок щільно зрощений з окістям та зубом на рівні емалево-цементної межі (стрілка). Забарвлення гематоксиліном та еозином. ×100. 
ває ясенні сосочки. За рахунок більш розвиненого остистого шару епітеліоцитів внутрішній епітелій вільної частини ясен товстіший, ніж зовнішній. Судини мікроциркуляторного русла, близько розташовані до власної пластинки слизової оболонки ясен, були помірно кровонаповнені або порожні (рис. 2).

Результати морфологічних досліджень тканин пародонта інтактних щурів показали особливості будови цих тканин. Так, в епітеліальній пластинці наявна чітка пошарова структура, ззовні є тонкий зроговілий шар, це все є ознакою нормальної структури епітелію, що забезпечується процесом ортокератозу. Таким чином, структура пародонта щурів забезпечувала його функціонування в умовах постійного подразнення під час харчування. Отримані дані були потрібні для порівняльного аналізу морфологічних досліджень слизової оболонки ясен тварин за умов експерименту.

Ясна тварин норм- і гіперергічної груп при експериментальному гінгівіті зазнавали морфологічних змін. У щурів нормергічної групи в епітеліальному пласті спостерігали розширення міжклітинних просторів, інфільтрацію нейтрофілами. Субепітеліальні тканини також були інфільтровані лейкоцитарними елементами. Найбільших змін зазнавали міжзубні ясенні сосочки, які були щільно інфільтровані нейтрофілами, місцями некротизовані (рис. 3).

У щурів з експериментальним гінгівітом і гіперергічним перебігом запальної реакції спостерігали зміни епітелію, що відповідають

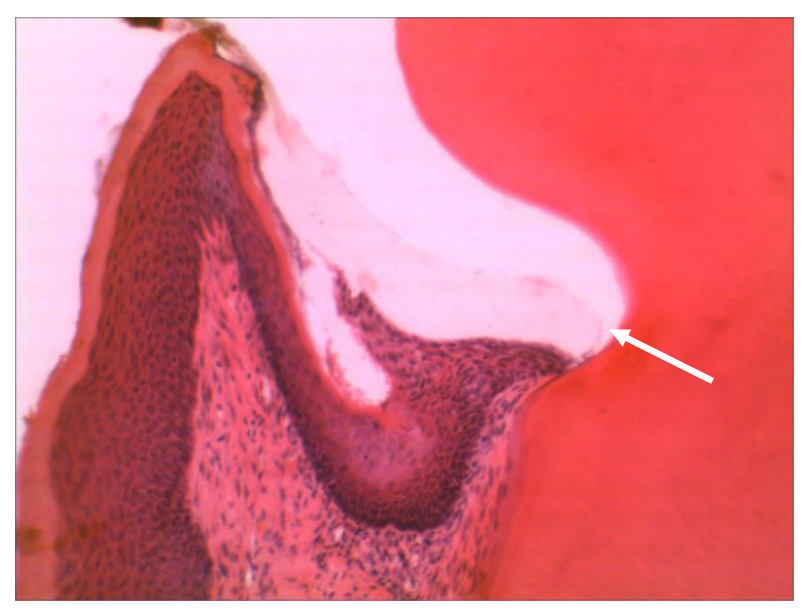

Puc. 2. Ясенний сосочок інтактного щура контрольної групи, щільно зрощений з окістям та зубом на рівні емалево-цементної межі (стрілка). Забарвлення гематоксиліном та еозином. $\times 100$. неспецифічному запальному процесу. Практично усі міжзубні сосочки укриті виразками або частково некротизовані, епітелій підростає під некротичні маси (рис. 4).

Епітелій ясен густо просочений клітинами запального інфільтрату (рис. 5).

Окрім того, часто спостерігали гіперпластичні процеси (рис. 6).

Окрім лейкоцитів, в епітелії сосочків виявлялись мікрокісти з елементами ороговіння (рис. 7).

Висновки. 1. Результати проведених гістологічних досліджень показали зміни структури ясен тварин при експериментальному гінгівіті без зміни реактивності організму. Зокрема, спостерігалися деструктивні зміни

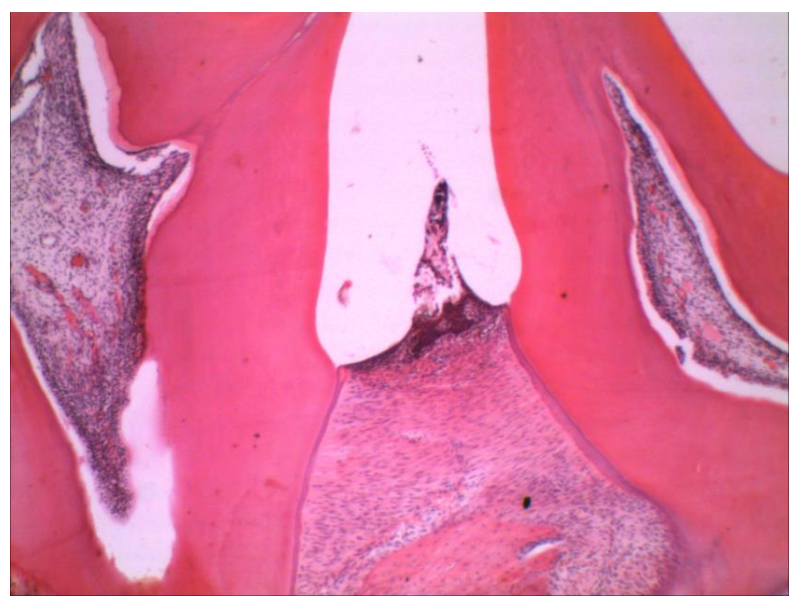

Puc. 3. Ясенний сосочок нормергічного щура 3 експериментальним гінгівітом. Масивний некроз ясенного сосочка. Забарвлення гематоксиліном та еозином. $\times 40$.

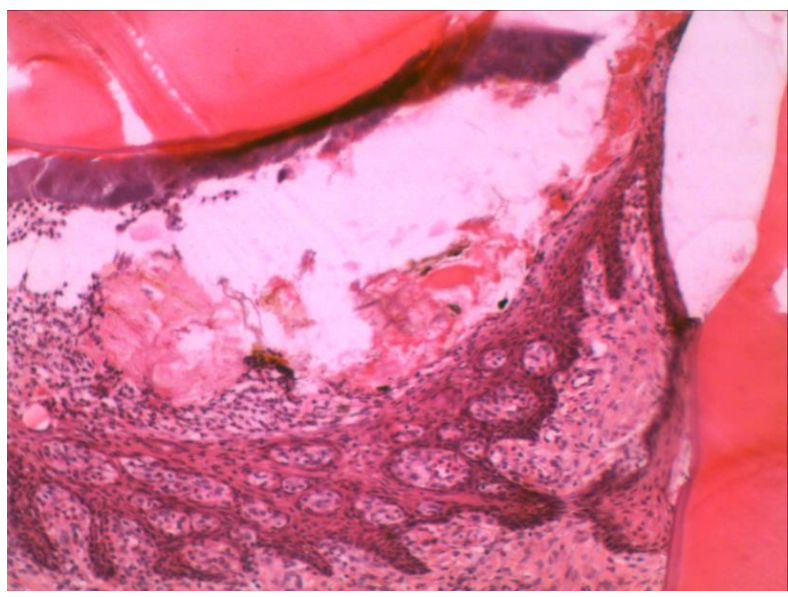

Puc. 4. Ясенний сосочок гіперергічного щура з експериментальним гінгівітом. Епітелій гіперплазований. Ділянка некрозу заповнена лейкоцитами і безструктурними масами, наявні ознаки паракератозу. Забарвлення гематоксиліном та еозином. ×100. 


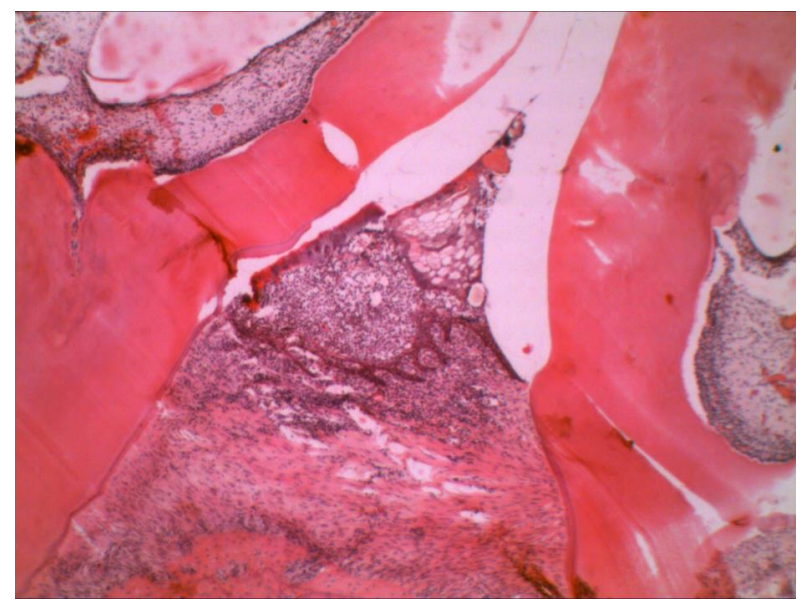

Puc. 5. Ясенний сосочок гіперергічного щура з експериментальним гінгівітом. Забарвлення гематоксиліном та еозином. $\times 100$.

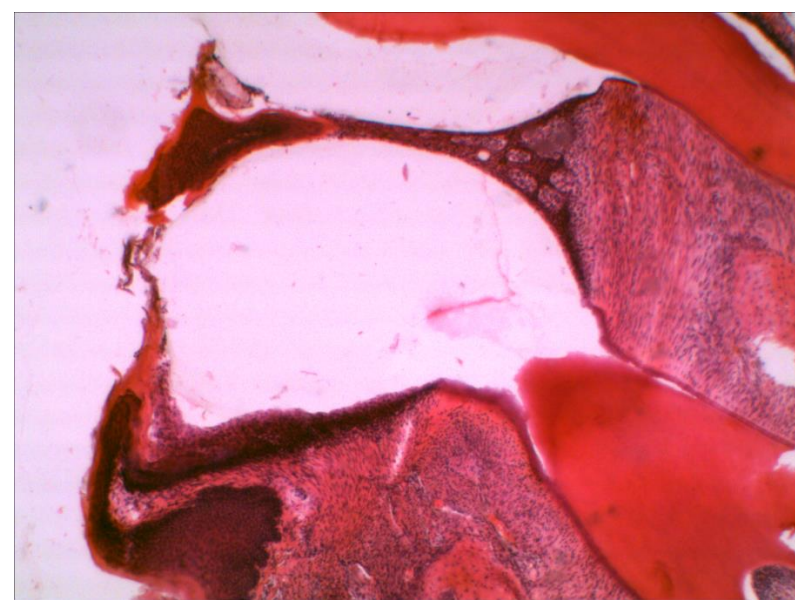

Puc. 6. Ясенний сосочок гіперергічного щура з експериментальним гінгівітом. Значна гіперплазія епітелію. Забарвлення гематоксиліном та еозиHом. $\times 100$.

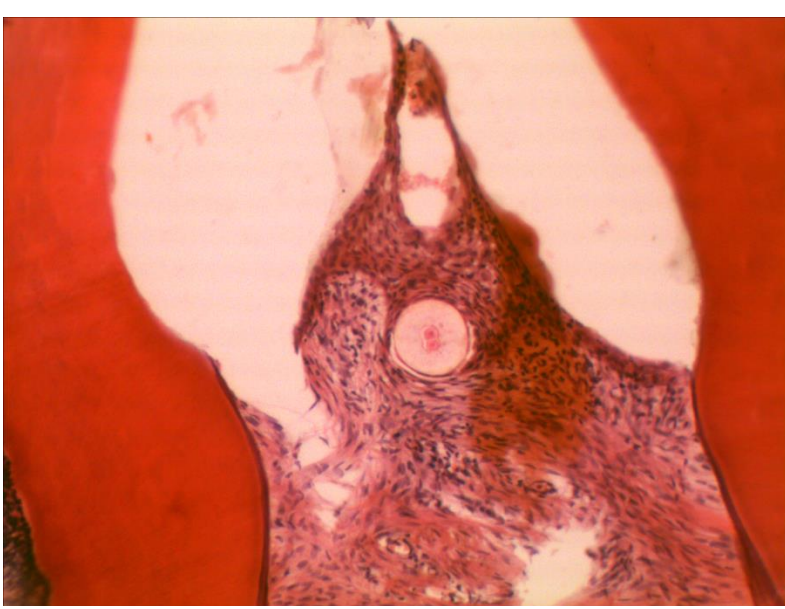

Puc. 7. Ясенний сосочок гіперергічного щура з експериментальним гінгівітом. Наявні мікрокісти 3 елементами ороговіння. Забарвлення гематоксиліном та еозином. $\times 100$.

епітеліального та сполучнотканинного шарів слизової оболонки; були наявні зміни епітелію: потовщення його зроговілого шару, ущільнення зернистого та остистого шарів; сполучної тканини: явища набряку, лейкоцитарної інфільтрації.

2. При моделюванні гіперергічного гінгівіту в пародонті виникав запальний процес, який характеризувався розвитком значної лейкоцитарної інфільтрації епітеліального пласту; часто спостерігалась як некротизація ясенного сосочка, так і його гіперплазія з проліферацію епітелію.

Перспективи подальших досліджень полягають у проведенні досліджень, направлених на вибір найефективніших заходів і засобів корекції гінгівіту з гіперергічним перебігом запальної реакції.

\section{(СР. А. Древницкая, А. В. Авдеев, А. Б. Бойкив}

Тернопольский национальный медицинский университет имени И. Я. Горбачевского МО3 Украины

\section{Структурные изменения тканей пародонта при экспериментальном гингивите с гиперэргическим течением воспалительного процесса}

Резюме. Для оценки морфологических изменений в тканях пародонта при экспериментальном гингивите с гиперэргическим течением воспалительного процесса было проведено моделирование этой патологии и экспериментального гингивита без воздействия на течение воспалительной реакции. Контролем служили гистопрепараты тканей пародонта интактных крыс.

Цель исследования - изучить морфологические изменения тканей пародонта при экспериментальном гингивите с гиперергическим течением воспалительного процесса. 
Материалы и методы. Были проведены морфологические исследования альвеолярного отростка с зубами и тканями пародонта интактных крыс и крыс с экспериментальным гингивитом в возрасте 5-6 месяцев. Микроскопически исследовали и фотодокументировали срезы толщиной 6-7 мкм, которые были закрашены гематоксилином и эозином.

Результаты исследований и их обсуждение. У крыс нормэргической группы в эпителиальном пласте наблюдали расширение межклеточных пространств, инфильтрацию нейтрофилами. Субэпителиальные ткани также были инфильтрированы лейкоцитарными элементами. Наибольшие изменения были в межзубных десневых сосочках, которые были плотно инфильтрированы нейтрофилами, местами некротизированы. У крыс с экспериментальным гингивитом и гиперэргическим течением воспалительной реакции наблюдались изменения эпителия, которые соответствуют неспецифическому воспалительному процессу. Практически все межзубные сосочки были покрыты язвами или частично некротизированы, эпителий подрастает под некротические массы, местами имеется гиперплазия эпителия, особенно верхушек межзубных десневых сосочков. Кроме лейкоцитов, в эпителии десен определяются микрокисты с элементами ороговения.

Выводы. Проведенныегистологические исследования установили изменения структуры десенживотных при экспериментальном гингивите без изменения реактивности организма. В частности, наблюдались деструктивные изменения эпителиального и соединительнотканного слоев слизистой оболочки; имелись изменения эпителия: утолщение его ороговевшего слоя, уплотнение зернистого и остистого слоев; в соединительной ткани были явления отека, лейкоцитарной инфильтрации. При моделировании гиперэргического гингивита в пародонте возникал воспалительный процесс, который характеризовался развитием значительной лейкоцитарной инфильтрации эпителиального пласта; часто наблюдалась как некротизация десневого сосочка, так и его гиперплазия с пролиферацией эпителия.

ключевые слова: гингивит; течение воспалительной реакции; структурные изменения десен.

\section{R. O. Drevnitska, O. V. Avdeev, A. B. Boykiv}

I. Horbachevsky Ternopil National Medical University

\section{Structural changes of periodontal tissues in experimental gingivitis with hyperergic course of inflammatory process}

Summary. To assess the morphological changes in periodontal tissues in experimental gingivitis with a hyperergic course of the inflammatory process, modeling of this pathology and experimental gingivitis was performed without affecting the course of the inflammatory reaction. The control parameters were histopreparations of periodontal tissues of intact rats.

The aim of the study - to study the morphological changes in periodontal tissues in experimental gingivitis with a hyperergic course of the inflammatory process.

Materials and Methods. Morphological studies of the alveolar process with teeth and periodontal tissues of intact rats and rats with experimental gingivitis aged 5-6 months were performed. Sections 6-7 $\mu \mathrm{m}$ thick, stained with hematoxylin and eosin, were microscopically examined and photo documented.

Results and Discussion. In rats of the normergic group in the epithelial layer observed expansion of intercellular spaces, infiltration by neutrophils. Subepithelial tissues were also infiltrated with leukocyte elements. The greatest changes were in the interdental gingival papillae, which were densely infiltrated by neutrophils, sometimes necrotized. In rats with experimental gingivitis and hyperergic course of the inflammatory reaction, epithelial changes corresponding to a nonspecific inflammatory process were observed. Almost all interdental papillae are covered with ulcers or partially necrotized, the epithelium grows under necrotic masses, in some places there is hyperplasia of the epithelium, especially the tops of the interdental gingival papillae. In addition to leukocytes, microcysts with keratin elements are identified in the epithelium of the gums.

Conclusions. Histological studies revealed changes in the structure of the gums of animals with experimental gingivitis without changing the reactivity of the organism. In particular, destructive changes of the epithelial and connective tissue layers of the mucous membrane were observed; there were changes in the epithelium: thickening of its stratum corneum, compaction of the granular and spinous layers; connective tissue: edema, leukocyte infiltration. When modeling hyperergic gingivitis in the periodontium there was an inflammatory process, which was characterized by the development of significant leukocyte infiltration of the epithelial layer; both necrotization of the gingival papilla and its hyperplasia with epithelial proliferation were often observed.

Key words: gingivitis; the course of the inflammatory reaction; structural changes of the gums. 


\section{СПИСОК ЛІТЕРАТУРИ}

1. Morphological and functional characteristics of human gingival junctional epithelium / Q. Jiang, Y. Yu, H. Ruan [et at.] // BMC Oral Health. - 2014. - Vol. 14. Article number: 30.

2. Condition of fagocytosis of experimental animals with periodontitis due to modified reactivity / O. V. Avdeev, R. O. Drevnitska, A. B. Boykiv, O. Ya. Vydoinyk // Wiad. Lek. - 2019. - Vol. 3 (72). - P. 401-404.

3. Пат. на корисну модель № 146655 Україна МПК

\section{REFERENCES}

1. Jiang, Q., Yu, Y., Ruan, H., Luo, Y., \& Guo, X. (2014). Morphological and functional characteristics of human gingival junctional epithelium. BMC Oral Health, 14, 30. 2. Avdeev, O.V., Drevnitska, R.O., Boykiv, A.B., \& Vydoinyk, O.Ya. (2019). Condition of fagocytosis of experimental animals with periodontitis due to modified reactivity. Wiad. Lek., 3 (72), 401-404.

3. Drevnitska, R.O., Avdieiev, O.V., \& Boikiv, A.B. (2021). Pat. 146655 Ukrainy na korysny model, G09B 23/28 (2006/01) Sposib modeliuvannia hinhivitu Z
G09B 23/28 (2006/01). Спосіб моделювання гінгівіту 3 гіперергічним перебігом запальної реакції / Р. О. Древніцька, О. В. Авдєєв, А. Б. Бойків винахідники ; заявник патентовласник Терноп. нац. мед. ун-т імені I. Я. Горбачевського. - № u202005763 ; заявл. 07.09.2020 ; опубл. 10.03.2021, Бюл. № 10/2021.

4. Патоморфологія та гістологія / за ред. Д. Д. Зербіно, М. М. Багрія, Я. Я. Боднара, В. А. Діброви. - Вінниця : Нова книга, 2014. - 805 с.

hipererhichnym perebihom zapalnoi reaktsii [Pat. 146655 Ukraine for utility model, G09B 23/28 (2006/01) The method of modeling gingivitis with a hyperergic course of the inflammatory reaction]. zaiavnyk ta patentovlasnyk I. Horbachevsky Ternopil National Medical University. - No u 202005763; zaiavl. 07.09.2020; opubl. 10.03.2021, Biul. No 10/2021 [in Ukrainian].

4. Zerbino, D.D. , Bahriy, M.M., Bodnar, Ya.Ya., \& Dibrova, V.A. (2014) Pathomorphology z gistology. Vinnytsia : Nova knyha. [in Ukrainian]. 